\title{
Shiraliyeva S.J.
}

DOI: 10.25108/2304-1730-1749.iolr.2015.45.169-194

\section{Integrative aspects of tactical combinations}

\begin{abstract}
The term of "tactical combination" is applied for indication of the tactical techniques and investigative actions in totality.

There dependence on each other and on investigative situation is existed between separate tactical techniques, separate investigative, organizational and investigatorysearching measures.

Tactical combination has common and concrete goals.

There is researched an admissibility and lawfulness of physical and mental influence, which have an important significance for integrative tactical combination.

The law has clear to define a notion of illegal mental impact and its components.
\end{abstract}

Keywords: integrative tactical combination; admissibility; lawfulness; physical impact; mental influence; coercion; violence.

In 1974 R.S. Belkin used the term "tactical combination" for denotation those technical techniques of interrogation, which named "psychological trap" or "investigative tricks", and later he broadened a notion of tactical combination, being included in it not only tactical techniques but also investigative actions [2, p. 16]. During formation of tactical combination concept R.S. Belkin studied ideas of A.V. Dulov about tactical operations, main content of which had concluded in the following: criminalistical tactics does not meet the needs of investigative practice as it is limited with development of recommendations directed in some investigative actions, while an investigator needs often to resolve the objectives, on which an answer might only be found through conducting a number of investigative, operational search, auditing and other actions. This is required necessity to solve the tasks of common nature demanding for their resolution conducting a group of

\footnotetext{
- Shiraliyeva Sabina Javanshir qyzy - PhD in Law, a member of Council of International Organization of Legal Researches (Azerbaijan). E-mail: mopi_sid@yahoo.com
} 
investigative, operational search, auditing actions, which denoted with concept of "tactical operations" [6, p. 23-26].

According to R.S. Belkin, there was one sufficient contradiction in the concept of A.V. Dulov. He named the issues of common and lesser common nature, which appeared during investigation, like tactical operations but not the means of these tasks' resolution, while a concept of operation is interpreted in theory of organization directly opposite way [1, p. 206].

Somewhat other definition of the operation was given by L.Ya. Drapkin. He believed that tactical operation is a complex of investigative, operational searching, organizational preparatory and other actions conducting on common plan and directed to resolution of some interim tasks subordinated to common goals of criminal case investigation $[4$, p. 54].

The first attempt of tactical operations classification also belongs to L.Ya. Drapkin, who divided them into: a) on a content - inhomogeneous tactical operations including investigative actions, operational searching measures and other actions, and homogeneous consisting only on investigative actions; b) on temporal structure - in through, production of which are carried out during few investigation's stages, and local tactical operations conducting in some one stage of investigation; c) on organizational structure - tactical operations fulfilled by the employees joined in permanent structural organizational link and tactical operations conducting by the employees joined in temporal structural functional link (investigative brigade, operative investigational group) [5, p. 54-55].

In 1976 V.I. Shikanov was offered the following definition of tactical operation: "Tactical operation is a system of consensual between each other investigative actions and operational searching measures conducting, in compliance with requirements of the norms of criminal procedural law, by authorized officials for clarification of the issues, which is a subject of proving on investigated by them criminal case" [19, p. 156-157].

In 1979 A.V. Dulov formulated a new definition of tactical operation, an essence of which was concluded that this "collection of investigative, operative, 
auditing and other actions developed and produced in process of investigation on common plan under guidance of investigator with purpose of tactical task, which might not be solved with production on a case of separate investigative actions" $[8, \mathrm{p}$. 44].

In 1997 R.S. Belkin was offered to consider that tactical combination is certain combination of the tactical techniques or investigative actions pursuing the objective of solution of concrete task of investigation and provided with this purpose and investigative situation [1, p. 201].

In 2000 we slightly changed this formulation being indicated that tactical combination is a certain combination of tactical techniques of conducting of investigative actions, organizational and operational searching measures, which applied for solution of common and concrete tasks of investigation and provided with these tasks and investigative situation [9, p. 394].

It was noted that systemacy, dependence each other and investigative situation, mutual determinacy determine the links between separate tactical techniques and also between separate investigative, organizational and investigational searching measures, between techniques, actions and measures [9, p. 394].

Establishment of the truth is a common aim of the tactical combination. The concrete goals of the tactical combination might be: creation of the conditions for conducting one or few investigative actions, organizational and operational searching measures; forming the conditions providing an effectiveness one or few investigative actions, organizational and operational searching measures; resolution of conflict situation through reflection; maintain of information sources safety; other impacts into investigative situation in order to change or use it [9, p. 394].

Tactical combination might be concluded in certain conjunction:

a) Tactical techniques carried out in frames of the one investigative action;

b) Tactical techniques of various investigative actions, organizational and operational searching measures;

c) Similar and dissimilar investigative actions, organizational and operational searching measures; 
d) Tactical techniques, investigative actions, organizational and operational searching measures.

As rule, the tactical combination is implemented in frames of concrete criminal case, investigation of which is presented itself a combination of certain actions of an investigator and other persons participating in disclosure of a crime [9, p. 394-395].

At the same time, tactical combination during investigation one criminal case may have significance on another criminal case or to be the tactical combination carried out in the frames of the two and more criminal cases. In base of these combinations is contained information about interrelation of criminal cases, which are joined in one production after conducting of the combination, or about relationships of the persons, who are figuring in the two cases on independent crimes.

Combination of the tactical techniques one investigative action with the tactical techniques other one is not a ground to make a conclusion about existence some conjunctive investigative actions as each investigatory action, being independent, is produced in certain procedural order.

The tactical techniques have also similar nature, though in whole and procedurally are not regulated, but used in certain situations. Tactical techniques of different investigatory action are combined, and are not mixed, inosculated, but not replaced each other. The same nature has combinational conjunction of investigative actions, organizational and operational searching measures [9, p. 395].

Consequently, the tactical combination is an open system of the tactical techniques, investigative actions, organizational and operational searching measures, the elements of which, forming of the subsystems, determine a kind of combination.

Tactical combinations are subdivided into the complex ones, content of which are the system of the tactical techniques, investigative actions, organizational and operational searching measures, and the simple ones, which consist on the system of the tactical techniques, are applied in frames of one investigative action.

The complex tactical combinations are subdivided into the similar ones, which consist on similar actions and measures, and dissimilar ones, which consist on different techniques, actions and measures, through and local ones. 
The simple tactical combinations are subdivided into the reflexive ones, the purpose of which is a reflexive managing with a person, who counteracts to investigation, maintaining and controlling implemented for checking of the right course of investigation, separate investigative actions etc.

Admissibility of the tactical combination is determined with admissibility of the goals of combination, tactical techniques, investigative actions, organizational and operational searching measures, and also with legitimate nature and ethicality their combination and impact into investigative situation and its components [9, p. 396].

On form of external reflection an impact might be physical and mental. It is not complex to determine a legitimate character of the physical impact. Investigator has the right to influence on the objects of inanimate nature and person in the bounds and cases caused by necessity appeared on case and the law prescriptions. Private and property rights and interests of the citizens should be limited in strict compliance with provisions of the law; caused property damage should completely be grounded.

It is inadmissible a physical coercion, physical impact into a person in process of proceedings. Exceptions are possible from this categorical rule only upon direct prescription of the law and are concerned the measures of procedural coercion: detention as a measure of restraint, appearance, forcible identification and obtaining of the samples for comparative examination.

There are distinguished two kinds of mental impact: illegitimate and legitimate. Illegitimate mental influence is violence over a person and is directly prohibited by the law in all forms.

It is only admissible a legitimate mental impact, but from that what to understand under this influence depends also determination of the impact means, recognition as legal and admissible or vice versa illegal and amoral those or others techniques and instruments of influence.

Let's consider in details indicated provision, i.e. together with deception they have a substantial significance for integrative criminalistical tactics.

There is absent a notion of physical and mental impact in the CPC of Azerbaijan Republic, though according to the article 15 of CPC, under violence a lawmaker 
understands "brutal, inhuman or degrading treatment or punishment", violating the rights of process' participants.

Particular, according to article 15.2 of the $\mathrm{CPC}$, "during criminal prosecution is prohibited: to apply torture, to use physical and mental impact, including medical preparations, to subject to cold, hypnosis, to deprive a medical aid, to apply other brutal, inhuman or degrading treatment and punishment" [16, p. 17].

Thus, an issue on admissibility of physical and mental violence in Azerbaijani criminal process is solved definitely: cannot.

At the same time, a lawmaker does not attribute the torture and threats to physical and mental violence, prohibits production of the actions "accompanying with prolonged or acute pain or temporary health disorder", provoking a lot of reasonable questions: whether admissible the actions, accompanying with short or non-sharpen pain; whether legally a constant disorder of health etc.

Not touching more obvious contradictions of the article 15 , let's try to state in outlines our vision of the violence's place in criminal process and criminalistics.

According to S.I. Ozhegov, violence is: a) application of physical force to somebody; b) coercive impact to someone, something; c) oppression, lawlessness $[11$, p. 334]. V. Dal writes that "violence is a restrictive, insulting, illegal and selfwilled action". Juridical encyclopedic dictionary determines violence in the law as physical and mental influence one man over other one, violating the rights the citizens to inviolability of person (in physical and spiritual sense), which is guaranteed with the Constitution [15, p. 84-85]. There notions of violence are absent in psychological dictionary edited by A.V. Petrovsky and M.G. Yaroshevsky [12], and also in "Psychology" (three volume edition) by R.S. Nemov [10].

The notion of violence is interpreted in different ways in legal literature and the worldwide legislative practice. So, R.D. Sharapov, based on the two main signs of violence - coercion and non-will, writes: "The true sense of the word "violence" consists in that it was marked and indicate now a certain action someone committed in respect of other one, opposite his/her will (desire)" [18, p. 20]. 
This and the same definitions of the notion "violence" are based on assertions of A.A. Piontkovsky about that "forcible impact into a personality consists in any coercion of his/her to the actions, which contradict to his/her desires" [15, p. p. 85].

According to L.V. Serdyuk, violence like external illegal impact into a man (or group of persons), which carried out against their will and is able to cause him/her organic, physiological or mental trauma and to limit the free expression of will or actions by him/her [14, p. 22].

In addition, being contradicted himself L.V. Serdyuk writes that violence, i.e. impact on a man or group of persons against their will, with purpose of crime prevention, i.e. an official violence is coercion [14, p. 13]. Meanwhile, violence and coercion are synonyms.

Model Penal Code of the USA attributes to violence not only "action constraining, insulting, illegal and self-willed", but also common a self-defence [15, p. 85].

F. Nietzsche pointed out in synonymous nature of the "violence" and "coercion" notions. He wrote on necessity of violence not only in state but also in personal scale for eradication of such psychological blemishes like laziness, nihilism etc. [15, p. 86].

Actually, discussion on content of "violence" notion is same that exists in criminal process and criminalistics concerning "deception" notion: similar actions of some participants of a process (witness, suspected, accused and other) are named a deception and other ones (an investigator, prosecutor and others) - investigative trick, psychological trap, combination, technique and others "camouflage" terms. According similar logics, if a pickpocket caught in flagrante delicto and beats a policeman then this is violence, and if the policeman beats back then this is coercion. According to L.V. Serdyuk and other scientists, in this case the legality of the actions acts like a border, though content of them is similar [14, p. 66].

Then it turns that exceeding the limits of necessary defence will be divided into the two parts: the first - violence, the second one - coercion; and suicide should be attributed to coercion, though it is a self-aggression - deliberate violence of a man over himself. 
"Violence" is a word and should be applied according to meaning: physical or mental coercion somebody to commit the actions against his/her will. Though, not everybody, who applies violence, is a rapist.

Any coercion presupposes impact, which is a component of it, and presented to be a process information transmission through various methods and means [17, p. 13]. Physical and mental impact and hence a coercion (violence) is subdivided in criminal process and criminalistics into legal and illegal one.

Legal physical influence (violence, coercion) in proceedings is considered to be only, which is permitted by the law, e.g. the measures of procedural coercion, investigative actions conducted forcibly, the measures provided to police by the Law "On Police" and others. Process of information transmitting from subject of impact (an investigator, inquiry officer) into an object of impact might slightly be distinguished from common. So, the law allows forcible deliver a person if there is no reaction to appear in police or a court transmitted by telephone or subpoena. A person, who did not react proper to information of an investigator about necessity to production of personal search, can be subjected to forcible way with applying of violence. A detainee, who is refused entering into a cell, can coercively be placed there.

An issue on mental impact (coercion, violence), where frames outlined not so obviously, is solve more complex.

Until now, the most part of procedures' specialists and criminalists consider that main sign of legal mental impact is recognized a freedom of the position choice, which is subjected to impact [13, p. 195], presence of the conditions for choice and state his/her position [7, p. 165], non-contradiction to lawfulness and moral principles of society [1, p. 220-221]. In addition, some scientist believe that selectivity factor, i.e. direction of impact only certain persons and neutrality in respect others, is the legality condition of mental impact [13, p. 202].

In our opinion, obvious at first sight, assertions do not solve an issue on legality or illegality of mental influence. So, legality means that mental impact has not to contradict to the law [1, p. 220]. If based on the article 15 of the CPC of Azerbaijan 
Republic, which bans all types of mental influence (violence), then the matter might be considered exhausted. If come deeper to the issue solution then it appears vicious circle: the law does not separate legal violence from illegal one, thereby it is excluded its application in whole. This, if not to take into account mention of hypnosis and deception in the article 15 of the CPC, ban of which has an arguable nature, and also threats, which is well-known.

Besides, in our point of view, lawfulness in this case is a second category as in order to prohibit or permit something in normative order, one need to determine its features, negative or positive nature.

Selectivity factor of impact does not call the objections, but it is not also a main one. Investigative actions, which are accompanied with impact, as rule, are conducted with one or two (confrontation) participants of process that provides a selectivity of an influence.

From the number of the ethic requirements, brought to impact, we should name the provisions developed by I.E. Bykhovsky, about which have talked above [3, p. 219-220].

The matters on freedom of position choice, presence of the conditions for choice and statement of his/her position, which seem obvious, content some contradictions as internal so external nature.

Conditions for choice and statement his/her position for suspected and accused are integrate elements of the freedom of self-incrimination and legal status, and for witnesses and victims - procedure of interrogation and other actions, conducting with their participation. They are clearly indicated in the law and do not call principal objections.

It is more complex an issue on the freedom of position's choice as this assertion, which has incomplete nature, contradicts to the objectives of criminal proceedings, excludes criminal prosecution and investigation of crimes. Investigation of crimes like process and its components, including lawful impact, one of the goals have changing a person's position, which is suspected in crime's commission. We are talking about confession and remorse, and on assistance in disclosure, refund of 
losses and other consequences of crime. What and how should crime be investigated for, if not to try changing the position of suspected, accused or false eyewitness?

One matter is, if chosen position is forced to leave through the threats, blackmail and other illegal techniques, but in other case one need to repeal and ban criminalistical tactics and method as their recommendations will become pointless and illegal.

In our point of view, notion of illegitimate mental impact and below indicated components of it should clearly be determined in the law. They are:

a) Threats application of physical violence during process presently or future, destroying property, distribution of defamatory data and other confidential information, criminal, disciplinary or administrative prosecution, obstruction of activity, violation other rights provided with Constitution and other laws of Azerbaijan Republic.

Threats might be addressed directly to a participant of process or in respect of other persons, independent on relative ties with process' participant;

b) Execution of the listed threats, including physical violence in respect of any persons having attitude to participant of process.

In this case illegitimate physical violence and other illegal actions in respect of some persons will be as the way of illegitimate mental violence in respect of participant of process;

c) Deliberate violation of the rights of process' participant like a man and citizen (except physical influence). In this case there are take into account Constitutional rights and freedoms, stipulated in chapter 3 of the Constitution of Azerbaijan Republic;

d) Deliberate violation of procedural rights of personality like a participant of criminal process $[15$, p. 90].

It seems that together with ethic requirements and selectivity of impact, which outlined in common features, have to make a base of criterion of lawfulness of mental impact. 


\section{References}

1. Belkin R.S. Kurs kriminalistiki t. 3: Kriminalisticheskie sredstva, priemy i rekommendatsii [Course of criminalistics: vol. 3: Criminalistical means, techniques and recommendations]. Moscow, 1997, 480 p.

2. Belkin R.S. Problemy opredeleniya posledovatel'nosti sledstvennykh deystviyi [Issues of determination of sequence of investigative actions]. Problemy uluchsheniya sledstvennykh deystviy i opertivno-rozysknykh mer $\mathrm{v}$ aspekte likvidatsii prestupnosti v SSSP [Issues of improving investigative actions and operation searching measures in aspect of crime's prevention in USSR]. Alma-Ata, 1974, pp. 16-21.

3. Bykhovsky I.E. Protsessual'nye I takticheskie sistemy sledstvennykh deystviyi [Procedural and tactical issues of the system of investigative actions]. Dis. dokt. yurid. nauk [Doct. Law Diss.]. Moscow, 1975, 315 p.

4. Drapkin L.Ya. Osobennosti informatsionnogo poiska $\mathrm{v}$ protsesse rassledovaniya i taktika sledstviya [Particularities of informational search in process of investigation and tactics of investigation]. Problemy uluchsheniya effektivnosti predvaritelnogo rassledovaniya [Issues of improving of effectiveness of preliminary investigation]. Leningrad, 1976, pp. 54-61.

5. Dubyagin Yu.P. Rukovodstvo po rozysku i rassledovaniyu neochevidnykh ubiystv [Guidelines on search and investigation of unobvious murders]. Moscow, 1997, 480 p.

6. Dulov A.V. O razrabotke takticheskikh operatsiyi pri rassledovanii prestupleniyi [On development of tactical operation under crime investigation]. 50 let Sovetskoy prokuratury i problemy uluchsheniya predvaritelnogo rassledovaniya [50 anniversary of soviet prosecutor' office and issues of improving preliminary investigation]. Leningrad, 1972, pp. 23-26.

7. Dulov A.V. Sudebnaya psikhologiya [Forensic psychology]. Minsk, 1975, 341 p.

8. Dulov A.V. Takticheskie operatsii pri rassledovanii prestupleniyi [Tactical operations under crimes' investigation]. Minsk, 1979, 126 p. 
9. Kriminalistika [Criminalistics]. Uchebnik dlya VUZov pod red. Suleymanova J.I. [Textbook for Universities, ed. by Suleymanov J.I.] Baku, 2000, 680 p.

10. Nemov R.S. Psikhologiya [Psychology], v 3 knigakh [in 3 books]. Moscow, 2001.

11. Ozhegov S.I. Slovar' russkogo yazyka [Dictionary of the Russian language]. Moscow, 1985, 797 p.

12. Psikhologiya: Slovar' [Psychology: Dictionary]. Pod red. A.V. Petrovsky i M.G. Yaroshevsky, 2 izdanie [ed. by A.V. Petrovsky and M.G. Yaroshevsky, $2^{\text {nd }}$ edition]. Moscow, 1990, 494 p.

13. Ratinov A.R. Sudebnaya psikhologiya dlya sledovateley [Forensic psychology for investigators]. Moscow, 2001, 352 p.

14. Serdyuk L.V. Nasilie: kriminologicheskoe i ugolovno-pravovoe issledovanie [Violence: criminological and criminal legal investigation]. Moscow, 2002, 384 p.

15. Suleymanov J.I., Shiraliyeva S.J. Problemy dopustimosti nasiliya v ugolovnom protsesse i kriminalistike [Issues of admissibility in criminal process and criminalistics]. Sbornik nauchnykh statey [Col. Sci. articles]. Nauka i obrazovanie [Science and Education], Baku, 2004 , no. 13, pp. 84-91.

16. Ugolovno-protsessual'nyi kodeks Azerbaijanskoy Respubliki [Criminal Procedural Code of Azerbaijan Republic]. Baku, 2001.

17. Khaydukov N.P. Taktiko-psikhologicheskie osnovy vozdeystviya sledovatelya na uchastvuyuschikh $\mathrm{v}$ dele lits [Tactical psychological basis of investigator's impact onto participating in case persons]. Saratov, 1984, $124 \mathrm{p}$.

18. Sharapov R.D.Fizicheskoe nasilie $\mathrm{v}$ ugolovnom prave [Physical violence in criminal law]. S. Petersburg, 2001, 308 p.

19. Shikanov V.I. Razrabotka teorii takticheskikh operatsiyi - vazheyshee uslovie sovershenstvovaniya metodiki rassledovaniya prestupleniyi [Development of tactical operations theory - significant condition of improvement of crimes investigation methods]. Materialy nauch.-practich. konferencii [Materials of Sci. Prac. Conf]. Moscow, 1976, pp. 155-159. 